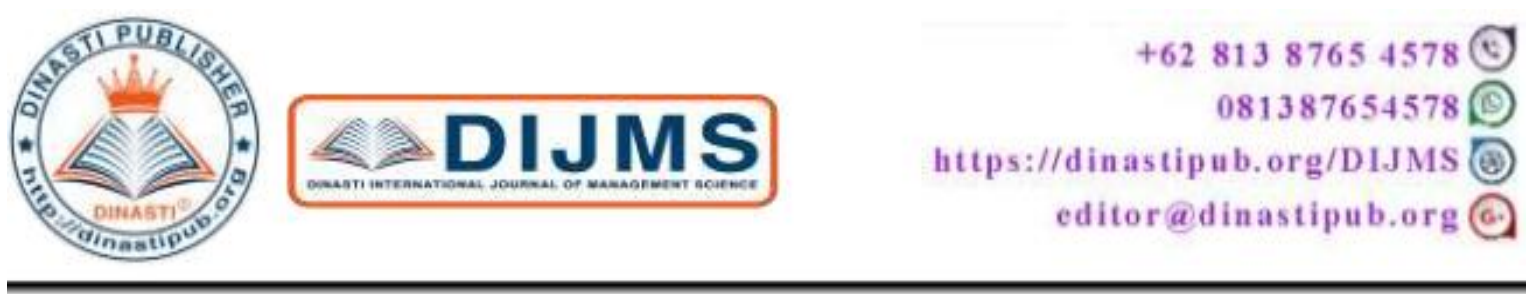

\title{
MENTORSHIP PROGRAM AS AN EFFECTIVE TEACHER DEVELOPMENT PROGRAM AT SEKOLAH PELITA HARAPAN IN INDONESIA
}

\author{
Rosma Indriana Purba'), Ratna Setyowati Putri' ${ }^{2)}$, Donna Imelda ${ }^{3)}$ \\ ${ }^{1,2,3)}$ Doctorate Research in Management, Pelita Harapan University, Indonesia
}

\begin{tabular}{|c|c|}
\hline $\begin{array}{l}\text { ARTICLE INFORMATION } \\
\text { Received : January } 13^{\text {th }} 2020 \\
\text { Revised : January } 16^{\text {th }} 2020 \\
\text { Issued : January } 19^{\text {th }} 2020 \\
\text { Corresponding author: } \\
\text { Rosma Indriana Purba } \\
\text { E-mail: } \\
\text { purba.rosma@gmail.com } \\
\text { ratnasetyowatiputri@gmail.com } \\
\text { deimelda18@ gmail.com }\end{array}$ & $\begin{array}{l}\text { Abstract: A mentorship program is cost-efficient and } \\
\text { effective ways to get employees engaged and } \\
\text { empowered. The program enable developing talent } \\
\text { and increase productivity across the organization. } \\
\text { The executive team of Sekolah Pelita Harapan has } \\
\text { grown a strong desire to help equipping educational } \\
\text { leaders to be effective in their role as educators. It is } \\
\text { founded on the belief that an excellent candidate } \\
\text { having a background of experience in education and } \\
\text { showing strong potential for further leadership } \\
\text { development can benefit enormously through the } \\
\text { opportunities that mentorship can offer. Through } \\
\text { several models of teacher development programs, it } \\
\text { was finally confirmed that the mentoring program } \\
\text { was an excellent way to develop teacher's } \\
\text { performance. } \\
\text { Keywords: Mentoring, job shadowing, active } \\
\text { application, dialogue, professional reading, self- } \\
\text { reflection. }\end{array}$ \\
\hline
\end{tabular}

\section{INTRODUCTION}

Parents, practitioners, and policymakers agree that the key to improving education is placing highly skilled and competent teachers in all classrooms (Hammond, 2010). Therefore, each school has a common responsibility to improve the quality of education, particularly new teachers, to be well-prepared and ready to teach. There are many ways to improve the teachinglearning processes. Through this writing, we will discuss teachers mentoring program for new teachers as one part of educational leadership.

School, as an educational institution has a primary role in making sure that its part runs as it is necessary. As a Christian school offering standards of education, Sekolah Pelita Harapan has a strong implication that the content of our teaching, as well as the teaching methods, practiced, are of the best. In its vision and mission, Sekolah Pelita Harapan aims to produce students who are challenged through holistic education, yet succeed academically, socially, 
emotionally and spiritually. Sekolah Pelita Harapan also commits to creating students who become qualified leaders, and significant contributors in Indonesia and throughout the world, becoming active global citizens as disciples of the Creator and to the development of the community (Sekolah Pelita Harapan prospectus handbook, 2010).

With these reasons, Sekolah Pelita Harapan involves teachers from different backgrounds of nationality and believes the most critical factor in determining high educational outcomes is the quality of teachers and strongly values the teachers as role models for students. The school also encourages teachers to challenge themselves as leaders among their colleagues in different expertise and to grow professionally.

Additionally, the school values teachers to set a very high standard for students, not just in what they know, but also in how they will use this knowledge in their everyday lives. Considering these aspects, Sekolah Pelita Harapan, then develop teachers mentoring program for new teachers to ensure that all teachers understand their roles within the community.

\section{LITERATURE REVIEW}

\section{New Teacher and Teachers Mentoring Program in Sekolah Pelita Harapan.}

In general, new teachers entering the profession, have to face several challenges. They are developing relationships with colleagues, joining both the school and the broader community of teachers, consolidating the knowledge they carry, gaining skills to facilitate them in their profession, and accepting or rejecting the norms and values of the school (Angelides and Mylordou, 2011). Accelerating the effectiveness of new teachers to the new system is a critical link to student success. Sekolah Pelita Harapan believes that new teachers need assistance to move from the initial orientation time through the professional practice time. It is also believed that new teachers must feel confident in doing their job, including expressing doubt or admitting mistakes, without fearing embarrassment or repercussions to take the responsibility well. In this respect, new teachers should be supported through teachers mentoring program and, in turn, students -- succeed in the classroom.

Teachers mentoring program is a popular form of teacher education. It involves a formal program of training by more experienced teachers for new teachers. Although teachers mentoring program has several benefits, essentially, it helps new teachers became successful in their teaching profession in the long-term (Wilkin, 1992; Ingersoll \& Kralik, 2004). Mentoring occurs when a more experienced educator (the mentor) provides support, guidance, advice, and encouragement to a newcomer or less experienced teacher to facilitate instructional improvement (Barrera et al., 2010 cited in Efron, Winter and Bressman, 2012). As a means of guiding and supporting practitioners to ease them through difficult transitions, teachers mentoring program is essential for unblocking obstacles to change building self-confidence and self-esteem as well as directing, managing and instructing (Fletcher, 2012).

\section{RESEARCH METHODS}

There are four critical components in the method of implementation towards the teachers mentoring program for new teachers in Sekolah Pelita Harapan. 


\section{Job Shadowing}

During the first quarter of the mentorship, new teachers will have an intense period of training where they will shadow their mentor in any possibility of teaching. Specifically, during this time, they will be observing their mentor closely to learn as much as they can about that mentor's interactions with teachers, students, parents, staff and administration. The new teacher will also be carefully observing how the mentor assigns priority to tasks and issues as they arise while continuing to lead the school in their day-to-day functions. Although not always possible, it will be ideal if the new teacher has the opportunity to observe their mentor during meetings and professional development. Then, during the second term, it is expected that the new teacher would have the opportunity to observe the Mentor in the following situations: creating a lesson plan, teaching, and department meeting.

\section{Active Application}

At the discretion of the mentor and based on the needs, the new teacher will be encouraged to do some tasks within the school community. These tasks would be guided carefully by the mentor. By the end of the interning period, there will be an expectation that the new teacher will be able to initiate and take full responsibility for some projects. Examples of such tasks would include:

- Reading and reviewing school policies

- Spending time informally observing the school community at different times.

- Informally entering classrooms to have quick observations of what is happening

- Attending extra-curricular student activities such as sports events and concerts

\section{Dialogue}

In order to provide a variety of connections and a web of support for new teachers, mentor teachers will not typically be from the same grade level or subject area as the mentee teacher. This relationship will likely start with basic, informational questions at the beginning and progress to more in depth discussion during the school year. Mentor teachers should touch base with the mentee teacher on a regular basis especially in the early weeks and months. There is no requirement for any set amount of time for this mentor/mentee relationship and both parties should be sensitive to the time constraints of the other person. Mentee teachers should feel free to ask questions about professional expectations at SPH, relationships with parents, teaching as a Christian, work/life balance, professional growth, teamwork within a professional learning communities, etc.

This component meant to help a new teacher to seek betterment. They are required to discuss, to share and to communicate anything that they have in mind related to the job, throughout the mentorship. The dialogue shall require both a new teacher and mentor to have a meeting weekly with the following purposes:

- Discussing any questions/issues arising from the experience of the mentorship experience from either the new teacher or the mentor

- Discussing with the mentor any issues and ideas rose through the course of their professional reading.

For any teachers mentoring program to be effective, it needs to take into account the issues new teachers and mentor to the profession. According to James B. Rowley's article that was published in 2006, there are eight problems that new teachers mostly deal with. They are:

1. Classroom discipline

2. Motivating students

3. Dealing with individual differences

4. Assessing student work 
5. Relationship with parents

6. Planning and organizing class work

7. Lack of materials and supplies

8. Students' problems

The eight problems listed above are some ideas and agenda to have during the dialogue. Further, in order to have a comprehensive dialogue, these ideas are suggested to be implemented as well.

- Meet regularly with the teacher assigned. Initiate a structured conversation with acclimation to education and teaching at Sekolah Pelita Harapan in Indonesia.

- Additionally, meet with the teacher and have structured conversation regarding their teaching experience. The conversation is a very separate item and probably a separate setting from the discussion on acclimation to education and teaching at Sekolah Pelita Harapan in Indonesia.

- Allow classroom visit at least twice each semester and provide follow up conversation.

- Share the professional development goals and how new teacher and the mentor work at professional growth.

- Pray regularly for the teacher assigned to both mentor and the new teacher. Pray also that both mentor and new teacher will be given the wisdom and spirit to guide their development

\section{Professional Reading and Self-Reflection}

All educators are leaders, and as such, should take responsibility for their continued professional growth. As part of this mentorship program, it is required that a new teacher will spend 3-5 hours per week in professional reading to help, to encourage teachers, to investigate issues and problems that have arisen in their own teaching experience and to search for solutions that will enhance their knowledge and skill base. Professional Reading time will be done on the teacher's own time. The reading sources could be taken from Professional Journals provided by school's subscription such as Christian Teacher's Journal, Christian School Education, Educational Leadership, and Nurture: Journal for Home and School. There are also some books available in the library to help them.

The goal of teachers mentoring program is to help the new teacher become a reflective practitioner; an educational professional concerned continuously with developing his or her knowledge base about the subject they are teaching and pedagogy employed (Weinstein and Munoz, 2014). Thus, aside from professional reading, new teachers are also encouraged to do a self-reflection. The school guides the new teachers on what to reflect on. The questions are: Question 1: What did I do this week to set the students up for success during the first days of school? Would I do anything differently for next year?

Question 2: What do I believe about how students learn? How does this belief influence instruction?

Question 3: If you had to reteach a lesson this week, what would you do differently and why?

Question 4: How's my teaming (partner/ team/greater team)?

Question 5: Have my students been able to achieve what was expected in the first unit? What needs to change/stay the same for the next unit for students to be more successful? 
Question 6: Which one component of the 5 Essential Elements (knowledge, concepts, skills, attitudes or action) has been a focus of my planning or teaching this term? How has focus impacted student learning?

Question 7: What differentiated learning strategies am I incorporating in my teaching, so all student needs are met?

Teachers are okay if they want to switch the order of the questions because of what happens to the classroom or if they want to repeat questions. Moreover, they are allowed to have other questions that they think will help them grow as a professional learning community. New teachers are encouraged to send their questions to the leadership team or mentor, and then the leadership team can forward them on for a follow up. The organization trusts that the teacher's leadership will grow effectively by allowing this.

\section{FINDINGS AND DISCUSSION}

\section{Statement of Outcomes and Project with Reflections}

A Guide to Mentoring of University of Auckland stated that through the mentoring program, there is personal benefit and satisfaction for both members of the mentoring partnership. Both participants gain new knowledge and skills in their school leadership through their exchange of ideas and practices. The teacher, being an extended professional, needs to evolve as a leader. With this fundamental information, Sekolah Pelita Harapan trust that teachers mentoring program will:

1. Provide a smooth, systematic entry to new teachers into understanding and participation in school culture and the community beyond the school.

2. Build greater confidence in new teachers as well as better teaching skills for both new teachers and participating teachers as they are paired over a period of time.

3. Encourage and create capacity for facilitative leadership and not lose sight of the fact that in each teacher, there is the inherent talent that needs to be unleashed.

4. Create a space for any teacher to display his/her leadership potential and thus add value to the organization.

After one semester, new teachers will be required to fill in a self-reflection checklist to evaluate how effective the mentoring program in helping new teachers in their understanding and participation in school culture and the community beyond the school and also their teaching professionalism. The checklist is as follows:

\section{A. Classroom Instruction and Management}

1 My knowledge of the content area is solid, "I know this stuff!".................4 321

2 I actively search for and use resources outside the textbook.....................4321

3 My classroom instruction is purposefully and sufficiently varied.................4321

4 My informal assessments, including times of verbal questioning, are intentionally crafted to include a full range of thinking skills....................................... 4321

$5 \mathrm{My}$ directions and explanations are clear, helpful, and positive.................4 321

$6 \mathrm{I}$ am regularly able to inspire students to give their best efforts..................4321

$7 \mathrm{My}$ assessments provide an accurate picture of student learning.................4321 
8 My classroom is orderly and safe. Misconduct is handled appropriately 4321

\section{B. Professional Responsibilities}

1 I regularly meet deadlines...............................................4 321

2 I regularly arrive on time to school, to chapel, to meetings, etc.................4 321

3 I regularly read professionally related material...............................4 321

4 I am growing professionally in specific, intentional ways.......................4 321

5 I am involved in students' lives and activities outside the classroom..............4 321

6 I willingly accept assignments, duties, requests, constructive criticism............4321

7 I am supportive of and positive toward the school..............................4 321

\section{Spiritual/Pastoral}

1 I have a strong understanding of and commitment to Christian Education.

2 I consistently use my homeroom time/position to "shepherd" my students

3 I participate joyfully and contribute meaningfully to chapel/retreats/prayer grp...4 321

4 I share my faith easily and often with students, parents, and colleagues...........4 321

Notes:

4...... I am confident in this area; a regular area of strength and encouragement for me

3 ......I am often successful in this area; usually, I experience good results

2 ...... I am not sufficiently confident in this area; I need good results to occur more regularly

1......I am sometimes discouraged in this area; it is keeping me from being as effective as I want to be

This self-reflection checklist will be looked over by principals. It gives principals better information about the effectiveness of the teacher's mentoring program on new teacher personal development in the first semester.

At the end of the academic year, new teachers and participating teacher as the mentor are asked to write paragraphs regarding their view of the mentoring process, the relationships that were formed, and the impact of teachers mentoring program on the teachers' professional practice. The writing will highlight areas where they have noted the growth in their understanding and application of teaching professionalism and as well as educational leadership. It will highlight four questions. They are:

1. What lesson, unit of study or resources did you find the most valuable? Describe why it was valuable to you.

2. What was the best quality work you produced this year? Describe why it was the best and what you learned from it.

3. What was the worst quality work you produced this year? Describe what you could have done to make it better.

4. What is your goal for next year?

This final reflection then will provide principals and administrator information about how much growth in their understanding and application of educational on his/her context as a new teacher and mentor teacher. Using these two evaluations, principals could evaluate if the new teachers will need another teacher mentoring program in the following new academic or not. It also enables us to know how much mentoring creates a space for any teacher to display both new teacher and teacher mentor's leadership potential and thus add value to the organization.

\section{CONCLUSION AND SUGGESTION}


A focus on the growth and development of our teachers is ultimately a focus on the learning and success of our students. The system described here allows Sekolah Pelita Harapan to answer the question on how the organization ensure that our teachers are providing mission appropriate, high quality instruction and feedback to our students. A comprehensive teacher development system should include elements of measurement-to ensure that minimum standards are being met-and development-to ensure that each year, each teacher is improving in her or his classroom practice.

The system described above includes these two areas while also incorporating elements that are specific to the success of Sekolah Pelita Harapan. Further, this system seeks to embed the internal teacher standards and the expected students outcomes into the heart of who the organization as education institution. Over time, we believe that effective teacher development will lead to improved school culture (Mielke \& Frontier, 2012), lengthened teacher tenure (Krasnof, 2014), increased parent satisfaction, and maximized student performance (ISM, 2012).

\section{REFERENCE}

Angelides, P. and Mylordou, A. (2011). The beneficial outcome of a successful mentoring relationship: the development of inclusive education. Teacher Development, 15(4), pp.533547.

Darling-Hammond, L. and Baratz-Snowden.E. (2007). A Good Teacher in Every Classroom: Preparing the Highly Qualified Teachers Our Children Deserve. Educational Horizons. 85, pp $111-132$

Feiman-Nemser, S. and Parker, M. (1993). Mentoring in context: A comparison of two U.S. programs for beginning teachers. International Journal of Educational Research, 19(8), pp.699-718.

Fletcher, S. (2012). Research mentoring teachers in intercultural education contexts; selfstudy. International Journal of Mentoring and Coaching in Education, 1(1), pp.66-79.

Ghosh, R. and Reio, T. (2013). Career benefits associated with mentoring for mentors: A meta-analysis. Journal of Vocational Behavior, 83(1), pp.106-116

Inc.com. (2020). 3 Reasons Your Company Needs a Mentoring Program. [online] Available at: https://www.inc.com/rhett-power/3-important-benefits-of-starting-a-mentoringprogram.html [Accessed 9 Jan. 2020].

Independent School Management | Advancing School Leadership_Enriching The Student Experience. (2020). Developing Faculty Through Coaching and Mentoring | Independent School Management | Advancing School Leadership_Enriching The Student Experience. [online] Available at: https://isminc.com/advisory/publications/ideas-andperspectives/developing-faculty-through-coaching-and-mentoring [Accessed 9 Jan. 2020].

Ingersoll, R. and Strong, M. (2011). The Impact of Induction and Mentoring Programs for Beginning Teachers. Review of Educational Research, 81(2), pp.201-233.

.McGinn, S. (2008). Becoming a High Performance Mentor: A Guide to Reflection and Action - By James B. Rowley. Teaching Theology \& Religion, 11(2), pp.110-111. 
Nwcc.educationnorthwest.org. (2020). [online] Available at:

https://nwcc.educationnorthwest.org/sites/default/files/research-brief-teacher-recruitmentinduction-retention.pdf [Accessed 9 Jan. 2020].

Weinstein, J. and Muñoz, G. (2013). When duties are not enough: principal leadership and public or private school management in Chile1. School Effectiveness and School Improvement, 25(4), pp.651-670. 